\title{
The establishment of a new ecological guild of pollinating insects on sub-Antarctic South Georgia
}

\author{
P. CONVEY ${ }^{1}$, R.S. KEY ${ }^{2}$ and R.J.D. KEY ${ }^{3}$ \\ ${ }^{I}$ British Antarctic Survey, NERC, High Cross, Madingley Road, Cambridge CB3 OET, UK \\ ${ }^{2}$ The Old Black Bull, Carthorpe, Bedale DL8 2LD, UK \\ ${ }^{3}$ Natural England, Alverton Court, Crosby Road, Northallerton DL6 1AD, UK \\ pcon@bas.ac.uk
}

\begin{abstract}
We report the establishment of two representatives of a new ecological functional group on the sub-Antarctic island of South Georgia - pollinating insects - in the form of the hoverfly Eristalis croceimaculata Jacobs (Diptera, Syrphidae) and the blowfly Calliphora vicina Robineau-Desvoidy (Diptera, Calliphoridae). The floricolous adults of these two species provide a new ecological role, pollination, in the ecosystems of this island. The activity of their respectively saprophogous or necrophagous larvae will also augment that of the native insect and microarthropod soil fauna. We discuss the potential new synergy between this functional group and that of a number of established non-native plants, reliant on insect pollinators for successful seed-set and hence dispersal, that are currently of persistent status with very limited local distributions.
\end{abstract}

Received 22 March 2010, accepted 6 July 2010, first published online 12 August 2010

Key words: bluebottle, calliphoridae, hoverfly, synergy, Syrphidae

\section{Introduction}

A feature of sub-Antarctic terrestrial ecosystems is the lack of native insect-pollinated plants, and pollinating insects, with plants relying on wind pollination, self-compatibility, or asexual means of reproduction (Smith 1984, Convey et al. 2006a, Convey 2007, Schermann-Legionnet et al. 2007). However, on some islands (notably South Georgia, Îles Kerguelen, Îles Crozet, and Marion Island) there are now a larger number of established non-native than native flowering plant species (Frenot et al. 2005, 2008), many of which would require insect pollination for successful seedset. The lack of native pollinating insects may have contributed to the failure of these established perennial non-native plants to make the transition from persistent to invasive status (sensu Frenot et al. 2005).

The majority of plant species currently considered to be invasive across the sub-Antarctic islands belong to windpollinated or self-fertile groups (Frenot et al. 2005, Convey et al. 2006b). Frenot et al. (2005) further conclude that, at present, most non-native plants that have established in the sub-Antarctic are of persistent rather than invasive status, with restricted or very restricted distributions where they do occur. For instance, only seven of the 69 species established on Îles Kerguelen and seven of the 59 species on Île de la Possession (Îles Crozet) are invasive and widely distributed on these islands. However, these few invasive species are already of considerable ecological significance. For instance, the distribution of Stellaria alsine Grimm, which arrived on Île de la Possession between 1989 and 1996, is expanding rapidly (Frenot et al. 2001), and it is displacing native species. It is a species that produces abundant and highly dispersible seeds. Likewise, on Marion Island, Sagina procumbens L. has expanded in extent rapidly (Gremmen \& Smith 1999), and a second invasive, Agrostis stolonifera L., dominates various habitats, impacting both vegetation and associated soil fauna (Gremmen et al. 1998). The only invasive non-native plant that is currently widespread on South Georgia is Poa annua L., although five others (Cerastium fontanum Baumg., Rumex acetosella L., Taraxacum officinale Wigg, Deschampsia caespitosa (L.) Beauv. and Poa pratensis L.) are found up to at least $1 \mathrm{~km}$ from sites of previous human occupation on the island (Walton 1975, McIntosh \& Walton 2000).

Here, we document new records obtained on South Georgia during the 2005/06 austral summer, and confirmed by targeted survey work during the 2008/09 summer, of the establishment of representatives of two important families of pollinating insects. Both are previously unrecorded or unconfirmed formally from the island, and one from the sub-Antarctic more generally, and pollinators represent a guild or ecological functional group (see Simberloff \& Dayan 1991) otherwise not represented in native communities.

\section{Methods}

As part of a general survey of terrestrial arthropod diversity between 21 January-7 February 2006, ten locations around South Georgia were visited, 440 samples of various vegetation substrata collected for Tullgren-style invertebrate extractions, and records of flying adult insects made. The 2008/09 survey 


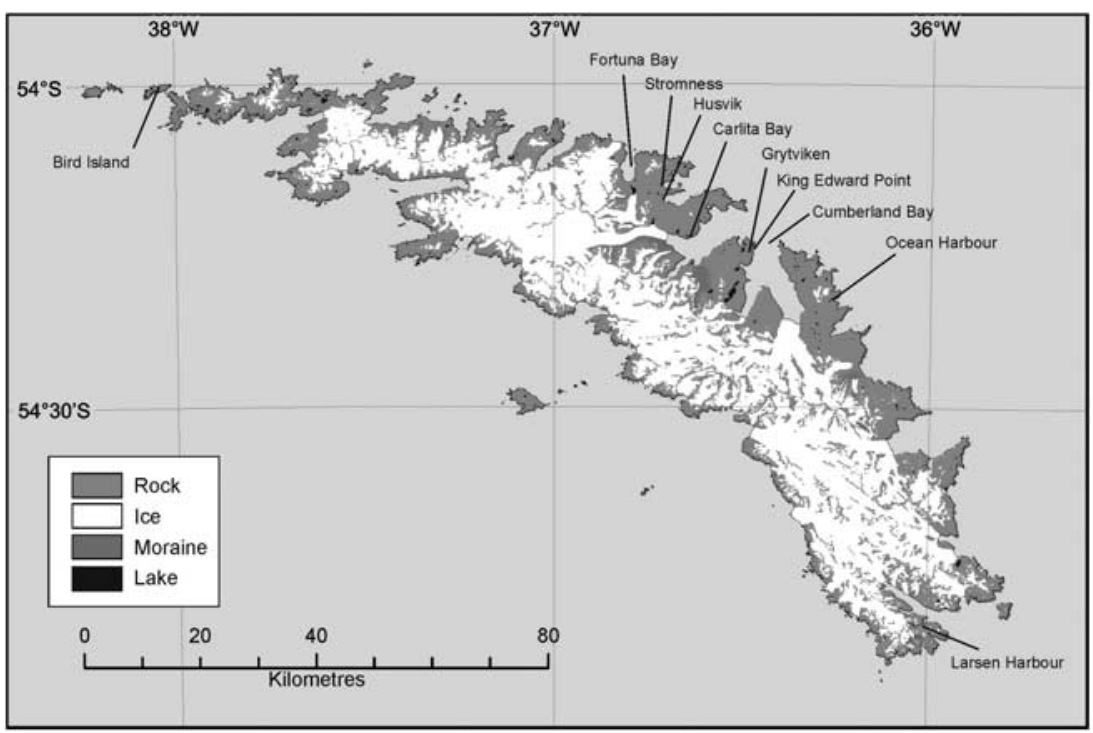

Fig. 1. Map indicating locations on South Georgia mentioned in the text. used a range of standard invertebrate sampling techniques, including Malaise and water pan traps, sweep netting and active observation, obtaining 655 samples of the invertebrate community from 15 locations along the northeast coast of South Georgia between Bird Island and Larsen Harbour (see Key \& Key 2009; Fig. 1 illustrates all locations named in the text).

\section{New species records}

\section{Eristalis croceimaculata Jacobs (Diptera, Syrphidae)}

On 8 February 2006, a single hoverfly (Diptera: Syrphidae) was observed and photographed within the boundary of the abandoned Grytviken whaling station (Fig. 2a), but could not be captured. On 13 January 2009, numerous hoverflies were observed nectaring on dandelion (Taraxacum officinale) flowers in the 'brownfield' meadow in the vicinity of Grytviken station. Although these specimens were nectaring on a nonnative plant species, a further specimen was observed on the native burnet (Acaena magellanica (Lam.) Vahl.) (M. LeLec, personal communication 2009). Fourteen specimens were captured by direct stalking and netting. Additional specimens were obtained from three water pan trap locations within the Grytviken whaling station, one trap at the neighbouring King Edward Point, and one trap adjacent to the Stromness station. The identity of these specimens has been determined as Eristalis croceimaculata Jacobs (Diptera, Syrphidae; see Thompson 1997) by F.C. Thompson of the Smithsonian Institution. A further specimen had been seen and photographed earlier in the 2008/09 summer at the intermediate location of Carlita Bay (P. Lurcock, personal communication 2009) which, together with the observation at Stromness, indicates that the species is already spreading or may have colonized more than once. Further specimens have since been observed at Grytviken on 14 January 2010 (F. Prince, personal communication 2010).

Eristaline hoverflies normally breed in water or very wet organic material, and are often able to cope with eutrophicated conditions, high in organic matter and with low oxygen content, by breathing atmospheric air through the 'rat-tail' at the rear of the larva. There were a number of such water bodies (natural and anthropogenic) in the immediate vicinity of the collection locations, in the form of vegetation-choked pools, ochre-depositing ditches and seal wallows, as well as a cleaner, stony-bottomed stream crossing through the whaling station. These habitats were sampled for characteristic eristaline larvae, but none were found. Given a possible larval dependence on highly organic water bodies and the adult insect's requirement for nectar sources, the species is likely to remain restricted to sites with such combinations on South Georgia. The species is described as a pollinator of Patagonian plants by Devoto (2006), and showed an apparent preference for non-native dandelion Taraxacum offinale agg (Asteraceae), cow parsley Anthriscus sylvestris (L.) Hoffmann (Apiaceae) and creeping buttercup Ranunculus repens L. (Ranunculaceae) flowers at Grytviken, whose future spread on the island it may therefore assist through pollination.

\section{Calliphora vicina Robineau-Desvoidy (Diptera: Calliphoridae)}

During January/February 2006 abundant adult bluebottles (Diptera: Calliphoridae) were noted to be present within Grytviken station, particularly around flowering stands of the non-native cow parsley adjacent to some of the derelict buildings (Fig. 2b). In 2008/09 the species was noted and/or captured at almost all locations visited between Fortuna Bay and Ocean Harbour, but not outside this range. 

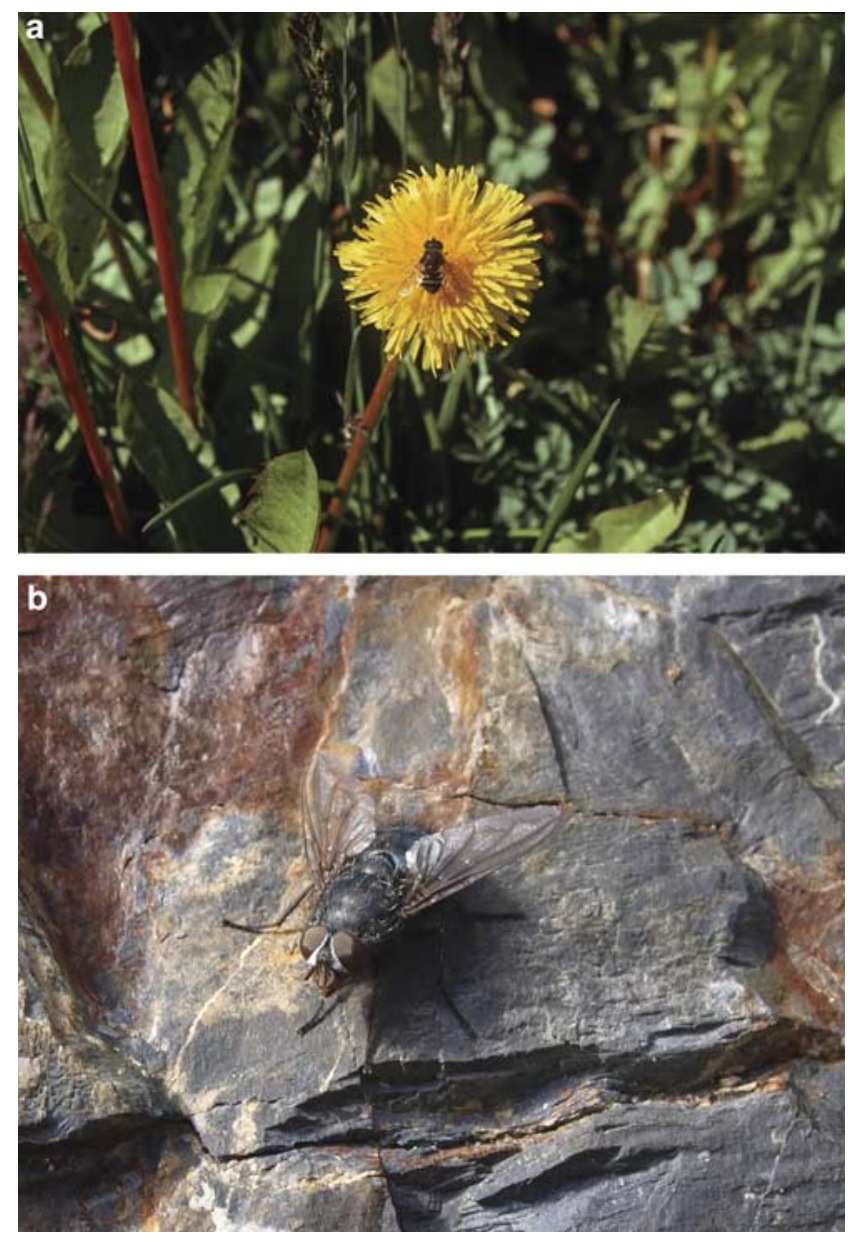

Fig. 2. a. Non-native hoverfly (Eristalis croceimaculata) observed on a non-native dandelion (Taraxacum officinale agg.) within the abandoned whaling station area at Grytviken on 8 February 2006 (photo: P. Convey). b. Non-native bluebottle Calliphora vicina, basking on rock at Ocean Harbour on 20 January 2009 (photo R.S. Key).

Although identification of this bluebottle has not been confirmed by specialist examination, specimens captured in 2008/09 key to Calliphora vicina in separate keys to blowflies of forensic importance in South America, the Holarctic and the United Kingdom (Ercinçlioglu 1996, Greenberg \& Kunich 2002). Calliphorid larvae were also found in a dead reindeer at Husvik in 2009, although these have not been identified to species. Carrion is widely available on South Georgia, deriving from the large marine vertebrate (especially seal and penguin) concentrations on the island. Calliphora vicina was first recorded from South Georgia at Husvik in 1994 (Hänel et al. 1998), although with no description of its status or distribution, and the species is well established in Patagonia and Tierra del Fuego (Schnack \& Mariluis 2004). This species has also been found on other South Atlantic islands, including a 1980 record from Beauchêne Island, the most isolated and southern island of the Falkland Islands archipelago (Smith \& Prince 1985). Although a second calliphorid has previously been recorded from South Georgia, the North American species Protophormia terraenovae (RobineauDesvoidy) (Hänel et al. 1998), this was not included amongst species known to be established on the island by Frenot et al. (2005) and no specimens attributable to this species were noted in the current study.

\section{Discussion}

The Grytviken area and other locations within Cumberland Bay are amongst the main tourist visitor attractions on South Georgia, recently attracting over 2500 visitors each summer season, arriving on the island on $\sim 50$ tourist vessels (along with $\sim 100$ other vessels, predominantly related to the fishing industry) (Frenot et al. 2005). The recent establishment of these two dipterans in the Grytviken/Husvik area of South Georgia, and, at least with Calliphora vicina, more widely along the milder north-eastern coast of South Georgia, is indicated by the records documented here, albeit without the confirmation of the presence of larval stages of Eristalis croceimaculata. However, the numbers present of the latter species, its persistence at the same site between years and its apparent spread indicates that it is almost certainly well established. Both species are known also from the Falkland Islands and Patagonia (Robinson 1984, Thompson 1997, Schnack \& Mariluis 2004), and C. vicina is nowadays of almost cosmopolitan distribution. Their location at two of the sites of highest human activity and, in particular, the only site of permanent human occupation on the mainland of South Georgia is highly suggestive of an inadvertent anthropogenic role in their transfer. However, it should also be recognized that these locations provide the most benign climate for terrestrial biota on the island, and thus may also be the most likely establishment location for a successful natural dispersal event from the Falkland Islands or southern South America.

As well as the adults performing a potential pollination role, larval C. vicina are likely to compete with or augment the role of indigenous dipterans, notably the helcomyzid fly Paractora trichosterna (Thomson), whose larvae occur in carrion as well as decaying kelp on the strandline, thereby altering the dynamics of decomposition. On South Georgia any impacts of such competition are clearly unknown. However, on Îles Kerguelen, the presence of C. vicina has been linked with a decline in the abundance of the indigenous dipteran competitor Anatalanta aptera Eaton (Chevrier et al. 1997). Similarly, on Marion Island, the non-native midge Limnophyes minimus Meigen, which can occur at very high densities, is proposed to contribute substantially to nutrient turnover, possibly rivalling the contribution of indigenous species that are currently a key limiting factor in nutrient release (Hänel \& Chown 1998).

Convey (2007) highlights the potential for synergies existing between different groups of non-native species on 
the sub-Antarctic islands. The current observations provide one such example, where a number of the non-native plant species known to be long-established but of persistent status and very restricted distribution on South Georgia (e.g. see Frenot et al. 2005, Osborne et al. 2009) may now have the potential for viable seed-set, and thereby be released from current limitations on their distributional expansion (see general discussion in Barrett et al. (1996). There is recent evidence that this is now happening on South Georgia (Osborne et al. 2009). Of the nectiferous, mainly insect-pollinated non-native plants on South Georgia, dandelion is already present at a wide range of sites of previous human occupation (McIntosh \& Walton 2000) and produces large quantities of viable seed, However, the other two main species, creeping buttercup and cow parsley, have a very limited distribution with, until recently, relatively little evidence of seed-based dispersal (Walton \& Smith 1973), although both have considerable potential to switch to invasive status (Osborne et al. 2009). In this context flower constancy, which is a characteristic of some hoverfly species, may also make an important contribution (see Goulson \& Wright 1998). Populations of both species have recently been found to have increased in number of individuals, and fruit set and seedling establishment, again of both species, was observed at Grytviken in January 2009 (Osborne et al. 2009). These increases may be directly related to the new availability of pollinating agents in the form of one or both of these flies; although at present this remains conjectural.

Remediation (eradication) measures are unlikely to be practicable or effective for either of the species of insect described here, given the practical difficulties of locating all individuals and life stages of an established and spreading insect, as well as their existing distributions on the island and the apparent abundance of potential habitat and food sources. The only relevant control measure to minimize the impact of this new synergy would be the selective removal of the most limited persistent non-native plant species requiring pollination, creeping buttercup and cow parsley. This would at least reduce the speed at which the potential synergy between them and the newly established pollinating insect becomes a reality and prevent these plants realizing their invasive potential on the island. However, given the already wide distribution of other invasive non-native plants such as the dandelion, such measures would have no impact on any future expansion of the distribution of these flies on the island.

\section{Acknowledgements}

We thank P. Vernon and an anonymous reviewer for constructive and helpful comments. PC is a member of the core BAS 'Polar Science for Planet Earth' research programme. Survey work in 2008/09 contributing to this publication (RSK \& RJDK) was undertaken as part of the
South Atlantic Invasive Species Project (SAISP), coordinated by the Royal Society for the Protection of Birds and BugLife, the Invertebrate Conservation Trust, and funded by the European Commission through EDF-9. This paper is also an output of the SCAR 'Evolution and Biodiversity in Antarctica' research programme. Eristalis croceimaculata was identified by F. Christian Thompson of the Department of Entomology, Smithsonian Institution, Washington.

\section{References}

Barrett, S.C.H., Harder, L.D. \& Worley, A.C. 1996. The comparative biology of pollination and mating in flowering plants. Philosophical Transactions of the Royal Society of London, B351, 1271-1280.

Chevrier, M., Vernon, P. \& Frenot, Y. 1997. Potential effects of two alien insects on a subantarctic wingless fly in the Kerguelen Islands. In Battaglia, B., Valencia, J. \& Walton, D.W.H., eds. Antarctic communities: species, structure and survival. Cambridge: Cambridge University Press, 424-431.

Convey, P. 2007. Influences on and origins of terrestrial biodiversity of the sub-Antarctic islands. Papers and Proceedings of the Royal Society of Tasmania, 141, 83-93.

Convey, P., Chown, S.L., Wasley, J. \& Bergstrom, D.M. 2006a. Life history traits. In Bergstrom, D.M., Convey, P. \& Huiskes, A.H.L., eds. Trends in Antarctic terrestrial and limnetic ecosystems: Antarctica as a global indicator. Dordrecht: Springer, 101-127.

Convey, P., Frenot, Y., Gremmen, N. \& Bergstrom, D.M. $2006 \mathrm{~b}$. Biological invasions. In Bergstrom, D.M., Convey, P. \& Huiskes, A.H.L., eds. Trends in Antarctic terrestrial and limnetic ecosystems: Antarctica as a global indicator. Dordrecht: Springer, 193-220.

Devoto, M. 2006. Interacciones planta - polinizador a lo largo de un gradiente ambiental: una aproximación en escala de comunidad. Ingeniero Agrónomo (2000, U.B.A.) MSc thesis, Magister de la Universidad de Buenos Aires, Área Recursos Naturales Escuela para Graduados Alberto Soriano, Facultad de Agronomía - UBA. http:// agro.uba.ar/ $\sim$ mdevoto/Tesis-MSc.pdf (accessed 31st March 2009).

ERCinçlioglu, Z. 1996. Blowflies. Naturalists' Handbooks, vol. 23. Slough: Richmond Publishing, 72 pp.

Frenot, Y., Gloaguen, J.C., Massé, L. \& Lebouvier, M. 2001. Human activities, ecosystem disturbances and plant invasions in subantarctic Crozet, Kerguelen and Amsterdam Islands. Biological Conservation, 101, 33-50.

Frenot, Y., Chown, S.L., Whinam, J., Selkirk, P., Convey, P., Sкotnicki, M. \& Bergstrom, D. 2005. Biological invasions in the Antarctic: extent, impacts and implications. Biological Reviews, 80, 45-72.

Frenot, Y., Convey, P., Lebouvier, M., Chown, S.L., Whinam, J., Selkirk, P.M., Sкotnicki, M. \& Bergstrom, D.M. 2008. Antarctic biological invasions: sources, extents, impacts and implications. In RoganFinnemore, M., ed. Non-native species in the Antarctic: Proceedings. Christchurch: Gateway Antarctica, 53-96.

Goulson, D. \& WRight, N.P. 1998. Flower constancy in the hoverflies Episyrphus balteatus (Degeer) and Syrphus ribesii (L.) (Syrphidae). Behavioral Ecology, 9, 213-219.

Greenberg, B. \& Kunich, J.C. 2002. Entomology and the law: flies as forensic indicators. Cambridge: Cambridge University Press, 306 pp.

Gremmen, N.M.J. \& Smith, V.R. 1999. New records of alien vascular plants from Marion and Prince Edward islands, sub-Antarctic. Polar Biology, 21, 401-409.

Gremmen, N.M.J., Chown, S.L. \& Marshall, D.J. 1998. Impact of the introduced grass Agrostis stolonifera on vegetation and soil fauna communities at Marion Island, subantarctic. Biological Conservation, 85, 223-231. 
Hänel, C. \& Chown, S.L. 1998. The impact of a small, alien macroinvertebrate on a sub-Antarctic terrestrial ecosystem: Limnophyes minimus Meigen (Diptera, Chironomidae) at Marion Island. Polar Biology, 20, 99-106.

HÄNEL, C., Chown, S.L. \& Davies, L. 1998. Records of alien insects from sub-Antarctic Marion and South Georgia islands. African Entomology, 6, 366-369.

KeY, R.S. \& KeY, R.J.D. 2009. Survey for baseline information on introduced plants and invertebrates. South Georgia. Invertebrates. Survey Report of the South Atlantic Invasive Species Project expedition to South Georgia, 24th December 2008-6th February 2009. Peterborough: BugLife - the Invertebrate Conservation Trust, 2 vols.

McIntosh, E. \& WALton, D.W.H. 2000. Environmental management plan for South Georgia. Cambridge: British Antarctic Survey on behalf of the Government of South Georgia and the South Sandwich Islands, 105 pp.

Osborne, J., Borosova, R., Briggs, M. \& Cable, S. 2009. Survey for baseline information on introduced vascular plants and invertebrates: South Georgia. Introduced vascular plants. Kew: Royal Botanic Gardens, 157 pp.

RoBinson, G.S. 1984. Insects of the Falkland Islands: a checklist and bibliography. London: British Museum (Natural History), 38 pp.
Schermann-Legionnet, A., Hennion, F., Vernon, P. \& Atland, A. 2007. Breeding system of the subantarctic plant species Pringlea antiscorbutica $\mathrm{R}$. Br. and search for potential insect pollinators in the Kerguelen Islands. Polar Biology, 30, 1183-1193.

SChNACK, J.A. \& Mariluis, J.C. 2004. Calliphoridae (Diptera) from southeastern Argentinean Patagonia: species composition and abundance. Revista de la Sociedad Entomológica Argentina, 63, 85-91.

Simberloff, D. \& DAyAN, T. 1991. The guild concept and the structure of ecological communities. Annual Review of Ecology and Systematics, 22, 115-143.

Sмith, R.I.L. 1984. Terrestrial plant biology of the sub-Antarctic and Antarctic. In Laws, R.M., ed. Antarctic ecology. London: Academic Press, 61-162.

Smith, R.I.L. \& Prince, P.A. 1985. The natural history of Beauchêne Island. Biological Journal of the Linnean Society, 24, 233-283.

Thоmpson, E.C. 1997. Revision of the Eristalis flower flies (Diptera: Syrphidae) of the Americas south of the United States. Proceedings of the Entomological Society of Washington, 99, 209-237.

Walton, D.W.H. 1975. European weeds and other alien species in the subantarctic. Weed Research, 15, 271-282.

Walton, D.W.H. \& Sмith, R.I.L. 1973. Status of the alien flora of South Georgia. British Antarctic Survey Bulletin, No. 36, 79-97. 